\title{
TONY ANGELO AND THE UNIVERSITY OF THE SOUTH PACIFIC
}

\author{
Sue Farran*
}

The University of the South Pacific is a regional university with twelve member countries consisting of island countries of the South Pacific region: Cook Islands; Fiji Islands; Kiribati; Nauru; Niue; Marshall Islands; Samoa; Solomon Islands; Tonga; Tuvalu; Tokelau; Vanuatu. Students from these countries and from others in the region such as the Federated States of Micronesia and Palau who are not member countries, come to study here. The administrative centre of the University and the original campus is located in Fiji but there are also campuses in Samoa and Vanuatu and regional centres in all member countries. 2008 marks the 40th anniversary of the University, which was first established under royal charter during British administration of Fiji. While Tony Angelo has not been associated with the University of the South Pacific for quite that long he has been involved with the Law School since, and indeed before, its inception.

Prior to 1994 the University of the South Pacific did not offer a Bachelor in Laws degree. There was a Department of Law within the School of Economic and Social Development, and legal education was by way of various Certificate of Law programmes which catered for those already in the legal profession of the islands, especially the public service. The Pacific Law Unit, located in Vanuatu, offered a Diploma of Law programme at sub-degree level. Most lawyers who practiced in the region were educated outside it or in Papua New Guinea. In 1992 the Council of the University resolved that the law programme should be located in Vanuatu and the first Bachelor of Laws programme was offered in 1994. Professor Tony Angelo was instrumental in the structuring and content of the new programme. He was one of two academic consultants invited to participate in the regional workshop held on the Emalus campus in Port Vila, Vanuatu in 1991 to draw up the curriculum for the law degree. Guy Powles, from Monash, was the other academic consultant, and Neroni Slade, now the Secretary General of the Pacific Forum, but then Attorney-General of Samoa, were approached for their expertise in Pacific law to advise the working party on the new programme.

At first students were taught at the Laucala Campus in Fiji but in 1996 the teaching of law undergraduates moved to Emalus, at the time a campus under construction, and when I first saw it in

* Senior Lecturer, University of Dundee Law School. She was formerly a Senior Lecturer and Associate Professor at the University of the South Pacific. 
1996 still a sea of mud. The first cohort of students there had to contend with snakes in the showers and student dormitories which had been located on land only recently cleared and on one notable occasion a student in class had a nasty shock when upon reaching for her textbook in her bag found instead a large snake - fortunately harmless. The first cohort of LLB students graduated in 1997 and now hold posts in the public and private legal sector throughout the region, some in very senior positons. In 1996 the School of Law was created as a separate entity and has continued to offer a range of sub-degree, degree and post graduate programmes. It has also been a focus for the development of South Pacific research and scholarship. Writing in 1998 the late Professor Bob Hughes, then Head of the School of Law, said: ${ }^{1}$

It is fair to say that when the USP law programme was initiated not many of the members of staff would have proclaimed themselves experts in the laws of the South Pacific region. There were very few legal academics at that time who could reasonably claim such a status in any event - apart from figures such as Tony Angelo, Don Paterson and Guy Powles.

While the staff have come and gone and heads of school have changed, Tony Angelo has been a continuing supporter of the University of the South Pacific in many different ways. He has participated as a visiting lecturer there, including on a course on Comparative Law, where he fascinated students with his contribution on Japanese law; through his contribution of materials to the library and more recently to the Pacific Islands Legal Information Institute (PacLII) especially as regards Tokelau. The Angelo family, in particular Mrs Angelo, Tony's mother, have generously endowed a scholarship enabling a Pacific Islander to travel to New Zealand, to the University of Victoria in Wellington, to study for a master's degree there. Krishn Shah, now a Senior Lecturer in the School of Accounting \& Finance, in the Faculty of Business \& Economics at the University of the South Pacific, was the first recipient of the Angelo Scholarship in 2000. He wrote: ${ }^{2}$

The issue of being awarded a scholarship was prestigious, and I was honoured to be the first recipient... It meant a lot to me, personally .... This was the same year that the Pacific was in crisis, with Solomon Islands and Fiji both experiencing riots. ..We were located in the old government buildings, opposite the Beehive ... It was a prestige to be in this wonderful building which was a conservation of architecture, and sightseeing in Wellington. I still recall the many nights that I sat in that building trying to work on essays, and papers.

1 B Hughes "Legal Education in the South Pacific" 5-6, author's copy.

2 Correspondence with the author. Krishn also commended the efficiency of the Victoria University of Wellington Foundation and the Office of the Dean of Law and wrote "My experience of Wellington and New Zealand generally was of a very hospitable and kind people where one feels humbled and feels the warmth from the hearts of the Maori, Pacific and New Zealand wider community". 
Meeting Professor Angelo was a memorable occasion, and he is a very jolly fellow ... who always had the extra time to hear out issues and who ... has made immense contribution to the development of law in the South Pacific.

The great thing about this scholarship and the Angelos was that they were accommodative and understood clearly the difficulties faced by Pacific island students. I felt comfortable discussing my future plans, and my problems with them and if a sponsor can get to mingle at that level, then indeed it is a prestigious award... Although I was the first person to take this scholarship, I knew that there would be many more.

Tony Angelo continues to be a regular visitor to the Emalus Campus, and his knowledge and expertise on Pacific law is sought by Pacific scholars within and beyond the region. He has become a point of reference not only for information, but also for ensuring the dissemination of a wider scholarship, for encouraging research and publication, and for securing standards of legal education in the region. Today the Law School has hundreds of students scattered across the South West Pacific. It delivers courses face-to-face in Fiji and Vanuatu and also by multi-modal flexible delivery using the internet, audio visual links and flexi-school ${ }^{3}$ in the summer and winter. While the content of the programmes have changed over the years the Bachelor of Laws degree remains the only accredited academic programme of study which leads either directly to admission to legal practice in the region or to the Diploma in Legal Practice and thence into the legal profession. Moreover the original aim of the Law School has remained the same: to produce graduates who are appropriately prepared for a wide range of employment and service opportunities within the region and to make an outstanding contribution to meeting the needs and demands of South Pacific communities. Tony Angelo has been, and continues to be, a key player in that mission and I am sure that law students would join with me in saying "Thank you/ Merci/Tank u tumas, Professor Angelo".

3 Intensive, partly residential distance courses held in University vacation time. 
